Goldschmidt 2021 Abstract

https://doi.org/10.7185/gold2021.6102

\section{Deep weathering of subsurface Fe- bearing minerals by Fe-metabolizing microorganisms in a semi-arid climate}

\author{
CHRISTOPHER SCHWERDHELM ${ }^{1}$, FERDINAND \\ HAMPL $^{2}$, LEA SAUTER ${ }^{1}$, CAROLINA MERINO ${ }^{3,4}$, \\ FRANCISCO MATUS ${ }^{3}$, FRIEDHELM VON \\ BLANCKENBURG $^{5}$, THOMAS NEUMANN ${ }^{2}$, ANDREAS \\ KAPPLER $^{6}$ AND CASEY BRYCE ${ }^{7}$ \\ ${ }^{1}$ Geomicrobiology, Department of Geosciences, University of \\ Tuebingen \\ ${ }^{2}$ Department of Applied Geochemistry, Technische Universität \\ Berlin \\ ${ }^{3}$ Universidad de la Frontera \\ ${ }^{4}$ Center of Plant, Soil Interaction and Natural Resources \\ Biotechnology Scientific and Technological Bioresource Nucleus \\ (BIOREN) \\ ${ }^{5} \mathrm{GFZ}$ German Research Centre for Geosciences \\ ${ }^{6}$ University of Tuebingen \\ ${ }^{7}$ University of Bristol \\ Presenting Author: christopher.schwerdhelm@uni-tuebingen.de
}

Mineral weathering shapes Earth's surface by transforming bedrock to soil in the 'critical zone'. Among these transformation processes, microbial weathering plays an important role, as it contributes to all stages of rock-soil transformation. Femetabolizing microorganisms, i.e. Fe(II)-oxidizing and Fe(III)reducing bacteria, are key players in weathering as they can directly attack minerals via their metabolism to gain energy. However, most direct evidence for the role of these microbes in critical zone processes comes from shallow and humid tropical soils and saprolite, or from transects across corestones. Much less is understood about the direct role of these microorganisms in deep critical zone processes in more arid climates.

In this study we have obtained drill cores from the critical zone of a semi-arid region in the Chilean Coastal Cordillera (Santa Gracia, NE La Serena). Despite receiving only $66 \mathrm{~mm}$ of rain per year, the weathering profile is deep $(>80 \mathrm{~m})$. The bedrock can be described as quartz monzodiorite, which is rich in hornblende, biotite, chlorite, magnetite and hematite but low in total organic carbon. We examined the bioavailability of $\mathrm{Fe}$ (bearing) minerals for $\mathrm{Fe}(\mathrm{III})$-reducing microorganisms along the depth profile by using geochemical, mineralogical and cultivation-based methods. Ratios of dithionite-extractable Fe to total Fe varied with depth and a generally decreasing ratio with increasing depth could be observed. Furthermore, we successfully enriched $\mathrm{Fe}(\mathrm{II})$-oxidizing bacteria in zones of weathered rock (up to ca. $25 \mathrm{~m}$ depth) and at the weathering front (70-76 m), while Fe(III)-reducing bacteria were enriched throughout the $87 \mathrm{~m}$ deep profile.

These findings suggest there is potential for Fe-metabolizing microbes to contribute to mineral-weathering processes even in deep weathering profiles in semi-arid environments. Despite much of the silicate minerals containing $\mathrm{Fe}(\mathrm{II}), \mathrm{Fe}$ (III)-reducing bacteria are more common. In summary, the co-occurrence of $\mathrm{Fe}(\mathrm{II})$-oxidizing and $\mathrm{Fe}(\mathrm{III})$-reducing bacteria points towards the presence of both electron donors (e.g. dihydrogen gas or organic carbon) for $\mathrm{Fe}(\mathrm{III})$ reduction and electron acceptors (e.g. oxygen) for $\mathrm{Fe}(\mathrm{II})$ oxidation. 